\title{
Censorship in Spain and Portugal of Spanish Films (1968-1974): A Comparative Perspective ${ }^{1}$
}

\author{
ANA BELA MORAIS
}

\begin{abstract}
Through an examination of the censorship reports made by the relevant authorities in Spain and Portugal between 1968 and 1974, I intend to study and compare the way that films from Spain were censored in those two Iberian countries during the last period of their respective dictatorships.

For Portugal, the present investigation is based on a study of the archives of the Secretaria de Estado da Informação e Turismo (SEIT). All the information produced by the Comissão de Exame e Classificação de Espectáculos, the section of SEIT which was responsible for the censorship of films under the Estado Novo, is to be found in the relevant section of the Arquivo Nacional da Torre do Tombo (ANTT), in Lisbon.

For the Spanish material, the study is based on the Expedientes de censura [censorship files] that can be found in the Archivo General de la Administración, in Alcalá de Henares. For Spain I also draw on the survey and analysis provided by Teodoro González Ballesteros (Aspectos jurídicos de la censura cinematográfica en España. Con especial referencia al período 1936-1977, 1981).

Through an analysis of the censored Spanish filmography in Marcello Caetano's and Francisco Franco's time, I aim to contribute to an understanding of the way the Censorship Commissions operated in each country. What, for example, were the most censored topics, thematically? This study may lead to a broader understanding of mentalities in Portuguese and Spanish history.
\end{abstract}

Keywords: censorship; Spanish films; Portugal; Spain; dictatorships

Through an examination of the censorship reports made by the relevant authorities in Spain and Portugal between 1968 and 1974, I intend to study and compare the way that films from Spain were censored in those two Iberian countries during the last period of their respective dictatorships.

Through an analysis of the censored Spanish filmography in Marcello Caetano's and Francisco Franco's time, I aim to contribute to an understanding

1 Translated from Portuguese by Richard Correll, including all quotes.

This study was made possible thanks to the post-doctoral fellowship that I was assigned by Portuguese Fundation for Science and Technology.

DOI: https://doi.org/10.12697/IL.2017.22.1.9 
MORAIS

of the way the Censorship Commissions operated in each country. What for example, were the most censored topics, thematically? This study may lead to a broader understanding of mentalities in Portuguese and Spanish history. ${ }^{2}$

For Portugal, the present investigation is based on a study of the archives of the Secretaria de Estado da Informação e Turismo (SEIT). All the information produced by the Comissão de Exame e Classificação de Espectáculos, the section of SEIT which was responsible for the censorship of films under the Estado Novo, is to be found in the relevant section of the Arquivo Nacional da Torre do Tombo (ANTT), in Lisbon. For the Spanish material, the study is based on the Expedientes de censura [censorship files] that can be found in the Archivo General de la Administración, in Alcalá de Henares.

For Spain I also draw on the survey and analysis provided by Teodoro González Ballesteros (Aspectos jurídicos de la censura cinematográfica en España. Con especial referencia al período 1936-1977, 1981). It would require either a large team or many of years of research to examine all the surviving documentation on Spanish censorship, and Ballesteros's work, despite being based on a subjective and selective survey of the censorship reports, seems to me to be the most complete and the one that most closely meets the required criteria. In this study, whenever data has been obtained from Ballesteros's work this is indicated in the notes. Where there is no such indication that is because the data were retrieved by myself, directly from Spanish or Portuguese archives.

In my research, I have included all the films that were censored in a given year, in both Iberian nations, even when they were approved without cuts the following year. For the purposes of this study I have dealt only with featurelength films that were censored, but not banned outright.

In both Iberian countries during the period of their respective dictatorships there was a preoccupation with the regulation of films produced locally, by national directors. That is to say, both in Portugal and in Spain the censorship of films produced by their own nationals was much stricter than that of foreign films.

Marcello Caetano replaced Salazar in Portuguese government in the end of 1968 and there he stayed until the end of the dictatorship in 1974.

The dictatorship of Francisco Franco was established in the country after the Spanish Civil War (1936-1939) and the end of the Second Republic. The Franco regime still survived the death of the dictator Francisco Franco (died November 20, 1975), to the self-dissolution of the Francoist Cortes in 1977.

Although both governments (Portuguese and Spanish) can be considered authoritarian, the Spaniard was more severe and brutal than the Portuguese. One of the main reasons that can explain this, relates to the existence of the Civil War, which happened just before the coming to power of Franco. 
$\overline{\text { Censorship in Spain and Portugal of Spanish Films (1968-1974): A Comparative Perspective }}$

As for the functioning of the censorship process, it was similar in both Portugal and in Spain, involving two stages, namely prior censorship of the script and final censorship of the completed film. In fact, the main difference between the two countries was in the use of dubbing. ${ }^{3}$

The preoccupation with the audience's understanding of what was shown or referred to in films may explain why only a small number of Spanish and Latin American films were approved for showing with cuts, in both Spain and Portugal. In fact, the great majority of cinematic production from those countries was simply banned. For example, in Portugal this was the case with the film Los días de Cabirio (Portuguese title As noites do delicadinho), a Spanish-Italian production, directed by Fernando Merino: it was banned on 28 December 1973. However, on 30 January 1974, a short time before the 25 April revolution, the director was given leave to appeal, and the film was given a group D classification, i.e. suitable for audiences over 18 , and shown without cuts.

The numbers speak for themselves: in Portugal, from a total of 1064 censorship proceedings analysed for the period between late 1968 and 1974, 31 concerned Spanish films and 11 concerned Latin American films. Of the latter group, four were Mexican, six were Brazilian, and one Hispano-Argentine. The fact that the greatest number were Brazilian once again suggests that the concern was to control those cinematic productions that were most understandable to a Portuguese-speaking audience.

This concern becomes even more obvious when we examine the number of films that were censored in Spain. Of 351 films we find 90 Spanish, including the following joint productions with other countries: nine Spanish-Italian, three Spanish-German, three Spanish-French, three Spanish-French-Italian, two Spanish-Italian-German, one Spanish-English, one Spanish-Swiss, and one Spanish-Italian-American. As for the Latin American productions, we find a total of nine films censored in Spain, of which four were Mexican, two Argentinian, one Spanish-Argentine, one Spanish-Venezuelan, and one Spanish-Mexican.

3 Due to the absence in Portugal of the facilities necessary to provide for the dubbing of the four hundred or so foreign-language films that entered the country each year, it was normal to use only subtitles. This use of subtitles in Portugal, as opposed to dubbing, habitually used in Spain, led to differences in the way that translations could be controlled. In Spain, the characters said whatever the censors wanted them to say, leading at times to results more startling than those they wished to suppress, whereas in Portugal the audience had the opportunity, if they understood the original language - in the present context, Spanish - to compare the original spoken words with the subtitles. On this crucial difference between the two countries, see Morais 2013. 
MORAIS

In Portugal, American films were the most censored, with a total of 365 - at this time the Portuguese market was dominated by the US cinematographic industry. In Spain, its own production was the most affected, with 90 films censored, following by America, with 38 films censored. These figures demonstrate that, in Spain, the censorship of national films was even more rigorous than that in Portugal, during the same period.

Let us look now at the censorship of Spanish films in the period from late 1969 to 1974, in both Spain and Portugal. The film La residencia/The Finishing School (Portuguese title Internato de raparigas), directed by Narciso Ibáñez Serrador, was the target of numerous objections from different censorship boards in Portugal. For example, in the report from those who first examined this film we read the following:

We hesitated to approve this film. Some dubious situations, streaks of homosexuality, scenes of physical violence and immorality between the girls, the physical relations that they keep, in turn, with the 'woodcutter boy' - all taking place in a boarding school 'run with an iron hand', in a dark and sinister atmosphere - these constituted negative aspects to be taken into consideration. Even so, we did not see sufficiently valid reasons to refuse the film a certificate $[\ldots]{ }^{4}$

In fact, on 15 October 1970, the film was classified

for adults, over 17 years, with the following cuts: a) suppression of subtitles 228 and 229 and corresponding images ['228 - Are you next? 229 - Eet's draw lots between those who want to go with him...': these subtitles are struck through in pencil]; b) suppression of subtitles 310 to 313 , including the corresponding images [' 310 - ... and until you see Henry. 311 - Fou only have to obey me... 312 - Obey me in everything Itell you. 313 - tt's the third night that Catarina's met up with him...': these are also struck through in pencil]; c) suppression of the images of the girls and sounds, around subtitle 391/392 [in pencil is written, at the side: 'enough - he undresses her sounds images of the girls'; double underlining by the censor]; d) substantial reduction in the scene of psychological torture to which Teresa is subjected, around subtitles 468 to 496 , particularly from subtitle 477.

4 This was the opinion of one of the censorship boards. As it was written on the report, by hand, I could not understand the exact date it was issued. 
Censorship in Spain and Portugal of Spanish Films (1968-1974): A Comparative Perspective

On 23 December 1970 the Comissão de Censura turned down the appeal made and decided to impose two further cuts: "a) scene of flagellation of supplicants following subtitle 169; b) scene with the mother's second kiss following subtitle 428. Trailer approved for adults with the removal of scenes ordered cut from the film."

In Spain, this film had already been censored in 1969:

Reel 3: in the scene with Señora Forneau and the pupil after her punishment, suppress the kiss on the back, ending the scene when the headmistress says: 'I'm sorry, Catalina'. Reel 6: suppress the caressing of the hands, leaving only the drying of the same. In the scene in the shower where Catalina shows herself naked in front of the headmistress, suppress the distance shot of the headmistress's gaze. Suppress shot in the shower of one of the girls showing her breasts. Reel 7: Suppress close-ups of moist, palpitating lips, when they are thinking of the scene unrolling in the woodshed between one of the pupils taking her turn with the wood-seller, as well as the shot of girl sewing slowly pulling the thread from her mouth, as an expression of what she is thinking. Reset the sound, suppressing only the sound of the gasping. Reel 8: Suppress only main shot of the mother kissing her son on the mouth, with the following scene to be kept, maintaining the yellow background. In the scene with the pupils in the attic, suppress only those naked images that don't affect the action and rhythm of the sequence. (Ballesteros 1981: 310)

This case seems to us one of the most revealing as regards the most censored topics, both in Portugal and in Spain: in it are cut images, subtitles and even sounds suggestive of homosexuality, physical violence, erotic love and aspects that challenge the moral, religious and ethical values of the regime, as well as figures in authority.

Another film that was censored both in Spain and in Portugal was El ángel (Portuguese title Um anjo dos diabos), directed by Vicente Escrivá. In Portugal, on 9 July 1971, the film was classified "in Group B, not authorized for audiences under ten years of age, with the suppression of subtitles 667, 668 [667 - 'If the Swedish girls don't come to Spain in the winter...'; 668 - '...We can box up the men and send them to Sweden.'] and 673 ['Physiologically I'm satisfied... Thank you!']. Trailer approved also for Group B.” In Spain, on 18 August 1969, the film was authorized "for all audiences, with the adaptations that follow: Reel 9: Suppress the phrases: 'Go to hell.' 'Se va a armar la de Dios es Padre.' 'Physiologically I'm satisfied." On 1 September 1969, the classification of the film was upheld, with the further suppression of the following phrases: "Why are you gambling with the law?'. And the reply: 'I'm not gambling with such an ugly lady.” 
MORAIS

Underlining the importance given by the censors to erotic love, taken as something that challenges morality and good behaviour, we cite the case of the film La casa de las palomas, directed by Claudio Guerin, a Spanish-Italian production, with a later English version. Its first Portuguese title, Perversão, was struck down and replaced by another which became definitive, equivalent to the original, A casa das pombas. The film was prohibited in Portugal on 26 April 1973. However, on 3 July 1973 it was classified

in Group D [over 18 years], with the following cuts: a) substantial reduction in the bedroom scene at the end of the fifth part; b) substantial reduction in the bedroom scene around subtitle 4 of the sixth part; c) cut of the scene of a couple entering the 'Casa de las Palomas' around subtitle 58 of the seventh part;

d) rejection of the Portuguese title 'PREVERSÃO'” [censor's own capitals and spelling].

In Spain, on 23 December 1971, this film was classified for those over 18 years of age, with the following cuts:

Reel 5: sequence of the delivery of Sandra: end with the background shot, seen through the fan, suppressing all the shots of the bed, except one of very brief duration, in the half-light, and which only shows the heads of the two. Reel 6: Suppress the scenes with Sandra and Fernando in bed, while Mariluz is knitting. Reel 9: Shorten the scene with Sandra alone in bed, leaving it reduced to the moment in which she jumps in.

On 11 March 1972, it was again given the same classification, but without cuts.

As well as sounds, often associated with erotic scenes, specific words or phrases were also censored. This happened in Portugal with the case of the $A$ mi las mujeres nifu ni fa (Portuguese title Para mim as mulheres nem fu nem fa), directed by Mariano Ozores, in which a phrase taken as having pornographic allusions was censored. The film was classified, on 17 April 1973, as "Group $\mathrm{D}$, with removal of the image in which a character pronounces a word that in Portuguese has a coarse meaning - between subtitles 569 and 570 [569 - Damn it. 570 - Nobody likes being with me], in the fifth part."

In Spain, this film was classified for those over 18, on 31 March 1971, with the following cuts listed on the reverse of the sheet: 
Censorship in Spain and Portugal of Spanish Films (1968-1974): A Comparative Perspective

Reel 1: soften the word 'suck them' as applied to women. Reel 3: Suppress the sequence in which the girl speaks of the young man who seven months ago left her embarrassed. Reel 4: Suppress from the song the verse 'If my sickness has no cure [cura], then I shall have to be ordained as a priest [also cura]'. Reel 5: Abbreviate the scene with Chanel, and suppress the phrase 'At the moment of climax I cry out and use swearwords', eliminating furthermore what is most offensive in the image or the expression. Reel 9: Suppress completely the scene of Pedro and Marcelo in the house.

One of the most censored matters was undoubtedly erotic love. In the consideration of the film Sangre en el ruedo (Portuguese title Sangue na arena), a bullfighting film, directed by Rafael Gil, there appears just the following remark, dated 10 November 1971, classifying the film as "Groups B, with a cut of the shot of hands on the legs, at subtitle 239. Trailer approved for Group B". The same happened with the film Simón Bolivar (Portuguese title Bolivar, o libertador), a Spanish-Italian production, directed by Alessandro Blasetti. The film was classified, on 17 September 1971, "Group C, with a substantial reduction in the love scene around subtitle 663 , so as to be limited to a very brief hint. Trailer in the same Group" [censor's underlining].

In Spain the film Sangre en el ruedo, was classified on 8 March 1969 as for audiences over 18, with the following cuts: "Reel 2: In the scene in which the magazine editor thrusts the stapler into a photo of the girl in a bikini, suppress the remark 'I'm getting old. My aim's getting bad.' Reel 3: Suppress shots of Rafael rubbing Ramona's thighs and comments alluding to what he has in his hands." However, as early as 8 May of the same year the film was classified as suitable for those over 14 years, without cuts.

The censorship of erotic love is linked to that of images of the naked body, which becomes as much censored as love, and associated with it (see Morais 2011). We find a particularly interesting case in which, amongst other things, the first Portuguese title - very explicit - is censored and another - more ambiguous - is approved. The censor's indecisiveness in substituting one word for another is very clear, and in the end he decides to remove all the subtitles in contention.

The film in question, by the Argentinian director Fernando Merino, had the Spanish title Préstame quince días. The proposed Portuguese title, Empresta-me a tua mulher por 15 dias was struck through in blue pencil, and written above, also in blue pencil, we read Empresta-ma por 15 dias, which was the title adopted definitively on 22 November 1972 . The film was classified on 8 September 1972, 
MORAIS

Group D, with the cutting of images corresponding to subtitles 642 to 646 inclusive, in the sixth part [642 - 'These stocking reach the waist.' 643 - sup. 644 - 'Here married women only use black stocking.' 645 - 'Do you know why?' 646 - 'For their sensuality.' Above the word lascívia (sensuality) the censor wrote, in blue pencil, lixívia (bleach), as if he had been thinking of substituting the word, but in the end he opted to cut this subtitle, and the preceding ones]. Trailer approved for Group D. Portuguese title Empresta-me a tua mulher por 15 dias rejected.

In Spain, this film was censored in 1971 with the following cuts: "Reel 6. Suppress the second and third shots focusing on the movement of the mattress on the bed. Also, the alternating shots of the nun praying and her satisfaction at the sound from the bed. Reel 9: In the scene at Alfonso and the girl's house, cut when he starts to unfasten her dress." (Ballesteros 1981: 320)

The Portuguese discussion of the film Tristana (Portuguese title Tristana, amor perverso), directed by Luis Buñuel, confirms that the censorship of erotic love is implicit in the censorship of aspects that challenge the moral and ethical values defended by the regime of Marcello Caetano, and that they go back to the time when Salazar was in charge. On 19 May 1971 the film was approved

for those over 17 years of age, with one cut, following subtitle 801, regarding the scene by the window and the mute man. In the trailer, the scenes to be suppressed are those that will not appear in the film, amongst them that previously mentioned, which corresponds to subtitle 36 . We regret that the title of the film, which seems to us improper, is already subtitled and departs from the original title, drawing attention to the perversity that constitutes the difficulty with this work by Buñuel.

On 20 August 1971 the cut following subtitle 801 was lifted.

In Spain the film Tristana was classified for those over 18 years, without cuts, on 2 March 1970 and again on 27 May 1970.

Other topics that were heavily censored, and quite revealing of the sensibilities of the time, were themes of war and peace, and anything that alluded, even indirectly, to the idea of a revolution with communist connotations. The handling of the film La orilla (Portuguese title Entre duas margens), directed by Luis Lucía, is instructive in this regard. The film deals with the Spanish Civil War and led to controversy in both Iberian nations. In Portugal, the first group of censors remark, in their report dated 24 November 1971: 
$\overline{\text { Censorship in Spain and Portugal of Spanish Films (1968-1974): A Comparative Perspective }}$

The action takes place during the Spanish Civil War and the story narrated in the film falls within the line of concord and appeasement attacked by the Franco government. The streaks of pacifism should, in our opinion, be considered in the context of a war between brothers and for that reason do not lead us to conclude that it condemns all wars, just or unjust. On the other hand, the film seems to be imbued with a certain progressive attitude, at the social level, which does not seem to us to form the basis for a decision to reject the film. It should be further noted that in religious terms the film is impeccable. [...]

A different group remarks in its report on 22 November 1971: "Given the political and military reservations (there are streaks of pacifism and fraternization with the enemy), this group, being assailed by doubts, cannot immediately approve or reject this film. In any case, should the film be approved [...]." On 25 November 1971 the film was classified "as Group C, with the following cuts: elimination of the subtitles 481,482 and 483 [concerning the army, though the subtitles appear to be incomplete]. But I inform Your Excellency that the Portuguese title given to the film in question, $O$ pecado de amar, was not approved." On 21 December 1971, the trailer was classified as "Group C, with suppression of the images corresponding to subtitle 24 [the subtitle read: 'Those of us working for the revolution']. I further inform Your Excellency that the Commission agreed to authorize the title proposed by the distributor, so that it comes to be called Entre duas margens."

In Spain, the film La orilla was classified for those over 14 years, without cuts, on 30 December 1970. However, despite being approved without cuts, this film drew many different views from the censors, as given by the "Comision de Apreciación de Películas”. This particular view is dated 27 April 1971. The censor says that in his opinion the film was not of "special interest". ${ }^{5}$ The censor, whose name is not evident, refers to the "report":

Good intentions pave the way to an infernal film. It's not that it is all bad apart from the intentions - it's that it's dreadful: script, direction, photography, music and even sound. Some actors acquit themselves, in the midst of this total disaster. To concede this the status of 'special interest' would be a heroic act of lese-cinematography. To extend advantages to it could fall within the orbit of the Penal Code [censor's own underlining].

5 "Special interest" implies: "elevación anticipo (10, 20, 30, 40 ó 50 \%)", "Doble protección: Económica, Doblaje, Cuota pantalla” and, for short films: "Subvención”; “Cuota pantalla, sencilla o doble”. 
MORAIS

The film, Adiós, cigüeña adiós (Portuguese title Adeus, cegonha adeus), directed by Summers, was censored both in Spain and Portugal, and for the same reasons.

In Portugal, the film was classified, on 14 September 1971,

in Group D, with the cut of the scene between subtitles 552 and 556 (included) [552 - Here we have the observances that could be most useful for those that have hopes. 553 - March is dedicated to São José, June to the Sacred Heart. 554 - May, Mary's month, dedicated to the most holy Mary. 555 - And the first five Saturdays to the Virgin of Fatima. 556 - It even seems that a priest will be born].

In Spain, on 16 August 1971, the film was classified for those over 18 years of age, with the following cuts: "Reel 2: Suppress speech by the College Principal. Reel 6: Suppress the phrase 'just a nun'. Reel 8: Suppress the expression by the Priest who says: 'A Paternoster for this world, because we don't know where it's going to.' Suppress apparition of sacred images to the ring of a 'gong." This film generated much debate amongst the censors and amongst the Colleges and religious institutions. At first it came close to being banned outright, and probably as a result of appeals the following report, no. 64.443, no. 4346 was issued:

La Comision de Ordenación en Pleno de la Junta de Ordenación y Apreciación de Películas at its meeting of the $17^{\text {th }}$ instant [November 1972] has resolved to revise the Spanish version of the Spanish-made film entitled 'Adiós, cigüeña, adiós', distributed by Warner Bros S.A. E. by passing the following resolution: To classify it as AUTHORIZED FOR THOSE OVER 18 YEARS, AND UNDER THAT AGE, TO 14, accompanied by their parents or persons to whose charge they are entrusted. (Section $d$ of the $2^{\text {nd }}$ paragraph the single article of the O.M. of 14 October 1972) with the alterations detailed on the back [those referred to above].

The film The Glass Ceiling (Portuguese title $O$ tecto de cristal), directed by Eloy de La Iglesia, was also censored, in both Spain and Portugal. In Portugal, on 13 April 1973, the film was classified "Group D, with a cut of the two girls in an intimate scene, at subtitle 531". In Spain, on 15 December 1970, it was classified for those over 18 years, "with the adaptations then detailed: Reel 2: soften dialogue of the countryman, substituting less coarse expressions, and replace the word 'touch up' (magreo) by 'caress' (manoseo). Reel 4: Suppress 'flash' in which Rosa's bare bosom appears."

At this point we can sketch out some conclusions. 
Censorship in Spain and Portugal of Spanish Films (1968-1974): A Comparative Perspective

A first observation to be made is on the difference in the total number of films censored during the period in question, i.e. 1968 to 1974, including Spanish and Latin American films. In Portugal there were 1064, and in Spain only 351.

As was mentioned above, the survey of information for Portugal was made personally, in the Torre do Tombo National Archive, and for the Spanish case was based in part on the resources of the Archivo General de la Administración, but above all on the study by Ballesteros. The latter, as I mentioned, makes a subjective selection of censorship cases, but it is, without doubt, the most complete survey and the most useful for the purposes of my research.

Of the 38 cases of censorship of Spanish films in Portugal, during the period of the Caetano government, the theme most often censored is undoubtedly erotic love, with 22 films affected.

In ten cases, there were themes that were censored explicitly because they challenged the moral or ethical values of the regime. As in Spain, these were often related to the censorship of erotic love, for example by the suppression of dialogues that hint at cases of prostitution or marital infidelity.

References to or images of nudity or physical violence were censored in seven cases each. References to homosexuality were censored in six cases. Direct or indirect allusions to communist revolution or other political themes were censored in five cases.

Of other topics, religion or war and peace were censored in three cases each. Sexual noises and swearing or phrases considered sexual or pornographic were censored two cases each. References to class struggle, criticism of figures in authority, allusions to the trafficking and consumption of drugs and to crime were also censored, in one instance each.

In Spain, the most censored theme was erotic love. Of the ninety films censored that were made in Spain itself, erotic love was censored in 53 cases, closely followed by nudity, in 47 cases. Closely related to these two themes we have the censorship of themes that challenge the moral and ethical values of the regime, which were the explicit object of censorship in 28 cases.

Topics related to religion were censored in 23 cases, homosexuality in 19, swearing or phrases considered to have an erotic or pornographic import in 17 cases, political topics in 12 cases and physical violence in eight cases. Three cases involve incest, two involve erotic gestures, while one involves references to war and peace, as well as erotic sounds.

The themes listed very often appear in combination, that is, in a single case there may be more than one theme that was censored. As we can observe, censorship of religion is much more rigorous in Spain than in Portugal. Spain was a confessional state all through the Franco dictatorship, while Portugal was 
MORAIS

and remains a lay state. Another matter more censored in Spain than in Portugal was that of swearing and erotic or pornographic language.

Another conclusion we can reach is that it was the censorship of erotic love that was preponderant, both in Portugal and in Spain. This can be explained by the swiftly increasing openness to the outside world that was being seen in both countries at this period. It came to the point that it was impossible to control completely influences coming from outside: the women's liberation movement, student revolts, defence of peace and opposition to war, particularly the war in Vietnam. The governments of Spain and Portugal did everything in their power to control this avalanche of events and values that went against the propaganda of their respective regimes, and censorship was undoubtedly considered one of the most efficient means of achieving that aim.

Censorship of erotic love and nudity is involved even in films that supposedly censored only in relation to crime or violence, such as in horror movies. For example, in Portugal the handling of the Spanish film Dracula Prisoner of Frankenstein (Portuguese title Drácula prisioneiro de Frankenstein), directed by Jesús (Jess) Franco, was classified on 6 September 1973 as Group D. The censors ordered "the following cuts: a) scene in which the servant kisses the dead girl around subtitle 39; b) cut to the scene in which Dr Seward grasps the crucifix around subtitle 140. Trailer approved for Group D, with the cutting of the scene in which the girl appears with bare breasts."

In Spain, on 4 August 1972, the same film was classified for those over 14 years, "with the following adaptations: Reel 5: Suppress the scenes in which Frankenstein's servant kisses the girl's body, before putting her into the oven." However, on 14 September 1972 the film was classified for those over 14 years, without cuts.

In the case of the censorship of Spanish films, there are six that were censored in Portugal, while in Spain the same films were approved without cuts. In Portugal, in the case of the film Las viudas (Portuguese title As viúvas), directed by Pedro Lazaga, the film was approved on 20 April 1967, with the suppression of the first story (there were four). On 2 December 1969 the decision was upheld. However, on 17 June 1970 the film was classified "for adults, over 17 years, without cuts."

This situation can be explained by the new openness seen in Spain in the second half of the 1960s, and this can also throw light on the smaller number of films censored in Spain, compared to Portugal. However, as Josefina Martínez points out, this openness never meant a "substantial transformation in the political regime', but rather a desire, albeit it rather slight, to loosen the strict controls of earlier decades" (Martínez, 2006: 333). As the author explains, this more 
$\overline{\text { Censorship in Spain and Portugal of Spanish Films (1968-1974): A Comparative Perspective }}$

liberal touch was due to the optimism that followed economic growth, the lack of a strong opposition, and a generational change that took place in the 1960s.

This liberalization was from the beginning more an economic than a cultural inclination, and should be regarded as quite uneven, given that Sánchez Bella, who took over from Fraga, reversed some of the concessions made and even tightened the censorship. From that late 1970s up to the end of the Franco regime there always existed a latent contradiction between the economic openness and the retrograde practices retained in the cultural sphere.

Portugal, in late 1968, when Marcello Caetano came to power, saw a slight relaxation, called by some the "Marcellist spring", but it soon proved to be illusory. This is evident from an analysis of the censorship proceedings during those years.

However - and the same could be said of Portuguese cinema throughout the Estado Novo - Spanish cinema productions during the Franco regime was always controlled both at the political and ideological level, by means of censorship, and at the economic level, since in order to make a film the producers had to obtain subsidies or other financial support.

The censorship of eroticism takes precedence over the censorship of violence in all proceedings, whether the films are Spanish or Latin American, both in Portugal and in Spain. The handling of the Spanish film Bajas pasiones, directed by Antoine de Bersy, in 1973, by the Spanish censors, shows how obvious and contrary to humanism this tendency is. Their report ends with this description:

Reel 2: In the scene at the ball, suppress the shots in which she bites the lobe of his ear. Reel 5: Suppress completely the sequence of homosexuality in the garden shed. Reel 8: From the final betrayal of Louise, all the shots are to be suppressed from when the chief of the 'roch' [band] tears her dress and throws her to the ground, up to that in which she bites his hand. Also to be suppressed is the scene in which she appears with breasts bare, on the ground. That is to say, the brutality is to be left in, and the other nuances are to be eliminated" [my emphasis]. (Ballesteros 1981: 328)

\author{
Ana Bela dos Ramos da Conceição Morais \\ anabelamorais7@gmail.com \\ Centro de Estudos Comparatistas \\ Faculdade de Letras da Universidade de Lisboa \\ Rua Rainha D. Luísa de Gusmão, nº 7, 20 I \\ 1600-685 Lisboa \\ PORTUGAL
}


MORAIS

\section{Primary sources}

Arquivo Nacional da Torre do Tombo: Fundo do SNI - Processos da Direcção Geral dos Serviços dos Espectáculos. Processos de Censura: 1968-1974.

Arquivo Nacional da Torre do Tombo: Fundo do SNI - Actas das sessões da Comissão de Censura 1968-1971 / DGSE Livro 29.

S.N.I., "Directrizes para uso da censura cinematográfica" [s.d.]. Consultado em Fundo MFR Pasta 009 (organismo detentor Cinemateca Portuguesa).

Archivo General de La Administación (AGA) - Alcalá de Henares.

\section{Bibliography}

António, L. 2001. Cinema e censura em Portugal. 2a ed. Lisboa: Biblioteca Museu República e Resistência.

Ballesteros, T. G. 1981. Aspectos jurídicos de la censura cinematográfica en España. Com especial referencia al período 1936-1977. Madrid: Editorial de la Universidad Complutense.

Buñuel, L. 1983. O meu último suspiro. Lisboa: Distri Editora.

Douin, J-L. 2001. Dictionnaire de la censure au cinéma. Images interdites. Paris: Quadrige /PUF.

Gil, A. 2009. La censura cinematográfica en España. Barcelona, Bogotá, Buenos Aires (...): Ediciones B / Grupo Zeta.

Gubern, R. 1975. Un cine para cadalso: 40 años de censura cinematográfica en España. Barcelona: Euros.

Martínez, J. 2006. El cine tardofranquista. Reflejo de una sociedad. - A. Mateos y A. Herrerín, eds., La España del presente: de la dictadura a la democracia. Madrid: Asociación del Historiadores del Presente, 333-353.

Morais, A. B. 2011. A censura ao corpo nos primeiros anos de governo de Marcello Caetano. - A. Valente, R. Capucho, eds., Avanca / Cinema. Avanca: Edições CineClube de Avanca, 27-32.

Morais, A. B. 2013. La censura cinematográfica en España y en Portugal: una primera aproximación. - J. F. Forniés Casals, P. Numhauser, eds., Escrituras silenciadas. El paisaje como historiografia. Alcalá de Henares: Universidad de Alcalá Servicio de Publicaciones, 61-66.

Neuschäfer, H.-J. 1994. Adiós a la España eterna. La dialéctica de la censura. Novela, teatro y cine bajo el franquismo. Traducción de Rosa Pilar Blanco. Barcelona, Madrid: Ministerio de Asuntos Exteriores y Anthropos Editorial del Hombre.

Ó, J. R. 1996. Censura. - F. Rosas, J. M. Brandão de Brito, eds., Dicionário de história do Estado Novo, Vol. 1 - A-L. Lisboa: Círculo de leitores, 139-141.

Torgal, L. R., org. 2001. O cinema sob o olhar de Salazar. Lisboa: Temas e Debates. 